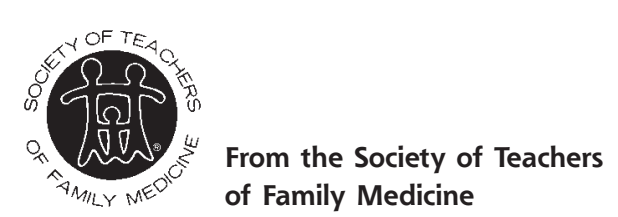

Ann Fam Med 2007;5:87-88. DOI: 10.1370/afm.674.

\section{STFM LEADS FAMILY MEDICINE INTO THE NIH ADVOCACY ARENA}

One morning in the fall of 2005, I was following my traditional routine of listening to National Public Radio as I drove to work. I was surprised to hear a story about the passion of Representative Joe Barton (R-Tex 6th), chair of the House Energy and Commerce Committee, for drafting a piece of legislation that would reauthorize the National Institutes of Health (NIH). While I knew that it had been more than 10 years since Congress had re-crafted the NIH through a reauthorization, I did not know that legislation was pending that could alter the direction of the NIH for the next decade or longer.

When I arrived at the office, I called Hope Wittenberg, MA, the Academic Family Medicine Advocacy Alliance lobbyist, to determine what policies family medicine had in place that could be shared with Congressman Barton and his staff regarding the role of family medicine in NIH. I should not have been surprised when Hope told me that family medicine had no policy and that we had never been a part of this debate. Advocacy efforts regarding research were directed at the Agency for Health Care Research and Quality—not $\mathrm{NIH}$. That made sense given the status of research within the world of family medicine when NIH was last reauthorized in the early 1990s. However, since the Future of Family Medicine report emphasizes the role of family medicine in scholarly activity, this was an opportune time to craft a statement for the family medicine community to rally behind.

In January 2006, a think tank was held in Arlington, $\mathrm{Va}$, that brought together family physician researchers and legislative advocates from across the country. The agenda for this meeting was to develop an advocacy plan for family medicine's role in the reauthorization of the NIH. During the course of the meeting, a plan emerged that would allow family medicine to play a central role in the emerging field of translational research. While NIH often talks about translational research as "bench to bedside," it was conceptualized that family physicians could evolve translational research into a broader concept taking basic science research from "bench to bedside to the community" and even further to the practice and patient level. In addition, it could also take community health issues and move them to a basic science question, thus making translational research bi-directional. While this idea makes sense, it was noted that translational research is part of Dr. Elias Zerhouni's, the current NIH director, Roadmap for Medical Research and is not codified into the NIH mission and purpose. When Dr. Zerhouni leaves his position, the concept of translational research may not continue unless it becomes a clearly indicated part of the NIH mission statement. Therefore, it made sense that we should try to get translational research integrated into the new law reauthorizing the NIH and its mission and purpose.

The next few months following the think tank meeting were quiet regarding the NIH reauthorization battle. Staff worked on development of language to support our goals while other key health issues such as physician payment, Title VII, and GME were actively pursued on the Hill and with the Department of HHS. However, with political winds changing during the summer, Congressman Barton made a new push for NIH reauthorization and in September 2006 passed a bill through his committee reauthorizing the NIH. Our Washington, DC, staff worked hard to get pieces of our translational research wording integrated into the bill, but Congressional staff and members did not want to entertain any amendments to the bill and quickly got the legislation passed through the House of Representatives with no changes.

On the Senate side, no move was being made to look at the NIH reauthorization language. There was a small victory for family medicine when the Senate Appropriations Committee passed its Labor/HHS spending bill for fiscal year 2007. While it did not codify translational research, it did state that the committee was supportive of translational research and strongly encouraged the NIH to integrate such research into a permanent component of their research portfolio. They specifically added that it was important to patients and their physicians, especially those who practice primary care. At the end of the last Congress, another power struggle ensued, with Congressman Barton holding up action on the Ryan White HIV/AIDS reauthorization as leverage for the Senate to act on the NIH reauthorization bill. So, in the final hours the reauthorization went through at great speed, with no amendments again, but revised from the House-passed version.

With the power structure on Capital Hill changing, no one is sure what priority will be placed on $\mathrm{NIH}$ reauthorization by the next Congress. With Representative John Dingell (D-Mich 15th) possibly chairing the House Energy and Commerce Committee and Senator Edward Kennedy (D-Mass) now chair of the Senate HELP Committee, family medicine will 
continue to work and develop relationships with their staffs to ensure that family medicine is an engaged participant in discussions regarding NIH. You can help by keeping an eye open for e-mails asking for your assistance and responding to these legislative alerts by calling your local Representative's and Senators' offices. There really is power to your voice and ideas; all you have to do is take the time to share them.

Terrence E. Steyer, MD Medical University of South Carolina Chair, STFM Legislative Affairs Committee

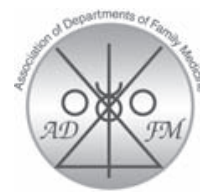

From the Association of Departments of Family Medicine

Ann Fam Med 2007;5:88-89. DOI: 10.1370/afm.671.

\section{INTELLIGENT DESIGN OR EVOLUTION? INNOVATION IN FAMILY MEDICINE RESIDENCIES}

Family Medicine Residency programs must innovate rapidly to attract applicants, compete for patients, deliver quality, and ensure that all graduates can deliver New Model care. However, powerful forces inhibit innovation precisely at a time when it should accelerate. This is the "innovator's dilemma": investment in an existing product makes fundamental change very difficult. ${ }^{1}$

From a national perspective, we must choose between alternative paths as we seek to recreate residency training: prescriptive, incremental change with predetermined outcomes vs unplanned, disorganized experiments with both failures and successes. In other words, we must choose between "intelligent design" and "evolution."

The choice is not simply between these 2 extremes; there are many points on the spectrum. However, ADFM believes we should move much farther toward "evolution" than we have to date. Failure risks extinction of the discipline of family medicine.

\section{Intelligent Design}

Careful, planned, incremental change in residencies is commendable. The Accreditation Council for Graduate Medical Education and its Residency Review Committees (RRCs), including the RRC-FM, exist "to improve health care by assessing and advancing the quality of resident physicians' education through accreditation." 2 Unstated is the premise that accreditation is intended to protect the public by enforcing minimum standards for residency programs. The RRC requirements are the organizational equivalent of DNA, the "genetic code" describing minimal structure and function for life of residencies. Accreditation follows change; it does not lead it.

The "family" of family medicine has taken important steps toward planned, incremental change in practice and training. The New Model of family medicine was developed after extensive research and widespread input ${ }_{i}$ TransforMED is helping 36 family practices implement the New Model. ${ }^{3}$ Keying off TransforMED, the ABFM, AFMRD, and AAFP have launched the Preparing the Personal Physician for Practice (P4) project to help residencies innovate. ${ }^{4}$ The $\mathrm{P} 4$ "experiments" will begin in 2007 and are expected to continue for 3 years, with evaluation of the changes in training a key part of the process.

The RRC-FM has new membership and a new executive director. We are hopeful they will be more supportive of experiments than the RRC-FM has been in the past, and that $\mathrm{P} 4$ will facilitate significant innovation. However, P4 will only work with a few programs, and it is not clear yet to what degree the RRC-FM will allow $\mathrm{P} 4$ residencies to deviate from requirements.

The process will also be slow. New RRC requirements, potentially incorporating results of "successful" P4 experiments, will not emerge for years. They represent one of our discipline's last chances to adapt to changes in medical practice for years. If this is our strategy, we better be right! Unfortunately, however, this is like assuming for ourselves the role of an omniscient "designer" to precisely anticipate future environmental pressures and implant the mutations in our "residency DNA" to ensure survival of our species.

\section{Evolution}

The alternative model is evolution, which occurs when there is sufficient genetic diversity in a population that some individuals have an adaptive advantage in the face of environmental change or competitive pressure. But diversity comes at a price: more mutations mean potential for failures.

We believe this model better describes the way family medicine should encourage innovation in our residencies. The practice of family medicine is already evolving rapidly. Family physicians are serving in a plethora of communities and environments, from large to small practices, corporate to independent work, New Model to retail clinics, hospitalist practice to low overhead practices to home visiting out of the trunks of cars.

There is no longer a single definition of family medicine. Family medicine is what people who call themselves family physicians do. Stated differently, in the high pressure ecology of practice, our species is already responding to "natural selection" forces in dif- 